\title{
6360 Sayılı Düzenlemeyle Oluşan Büyükşehir Modelinde Büyükşehir Belediyesi İle İlçe Belediyeleri Arasında Yaşanan Sorunlar ve Çözüm Önerileri: Hatay İli Örneği
}

Problems and Solution Proposals Between Metropolitan Municipality and District Municipalities in The Metropolitan Model Formed By The Regulation Numbered 6360: The case of Hatay Province

\section{Yakup BULUT}

Prof. Dr., Hatay Mustafa Kemal Üniversitesi, IIBB, Kamu Yönetimi Bölümü, yakupbulut@hotmail.com https://orcid.org/0000-0002-0838-4200

\section{Demet DÖNMEZ}

Dr. Ögrr. Üyesi, Hatay Mustafa Kemal Üniversitesi, Antakya MYO, donmezdemet@gmail.com

https://orcid.org/0000-0002-5833-9088
Makale Başvuru Tarihi / Received: 10.04.2019

Makale Kabul Tarihi / Accepted: 04.05.2019

Makale Türü / Article Type: Araştırma Makalesi

\begin{abstract}
Anahtar
Kelimeler:

Hatay,

Büyükşehir

Belediyesi,

İlçe Belediyesi,

6360 Sayılı Yasa,

Bu çalışma, 6360 sayıl düzenlemeyle oluşan büyükşehir modelinde büyükşehir belediyesi ile ilçe belediyeleri arasında yaşanan sorunlar ve bu sorunlara ilişkin aranan çözüm önerileri üzerinde durmaktadır. Hızlı kentleşme sürecine bağll olarak artan sorunlar, özellikle büyük şehir yönetimlerinin yeniden yapılandırlmasını gerekli kılmıştır. 6360 sayılı düzenleme böylesine bir ihtiyacı karşılamak üzere hayata geçirilmiş olsa da uygulamada başta yetki ve hizmet paylaşımı olmak üzere birçok sorun ortaya çıkmıştır. Bunların bazıları zamanla aşılmış olsa da bütün büyük şehirler için aynı şeyi söylemek zordur. Bu açıdan 6360 sayıl yasa başta yetki konusunda büyük değişiklikler içerdiğinden, yasanın yürürlüğe girdiği günden bu yana, sunulan hizmetlerin yeterliği ve kalitesi hep tartışma konusu olmuştur. Dolayısıyla Hatay ölçeğinde yapılan bu çalışmada, Hatay Büyükşsehir Belediyesi ile Hatay'daki ilçe belediyeleri arasındaki yetki, hizmet, kaynak, denetim ve koordinasyon gibi beş temel alanda işlevselliğinin hangi ölçüde să̆lanabildiği tespit edilmeye çalışılmıştır.
\end{abstract}

Keywords:

Hatay

Metropolitan

Municipality,

District

Municipality,

Law No 6360

\section{ÖZET}

\section{ABSTRACT}

This study focuses on the problems between the metropolitan municipality and the district municipalities, and the solution proposals regarding these problems, in the metropolitan model formed by Law No. 6360. The increasing problems due to the rapid urbanization process necessitated the restructuring of big city administrations. Although the Law No. 6360 has been implemented to meet such a need, in implementation, many problems have emerged particularly such as authority and service sharing. Although some of these are over time, it is difficult to say the same for all major cities. In this respect, since the Law No. 6360 contains major changes in the area of jurisdiction, the adequacy and quality of the services provided have always been the subject of discussion since the law came into force. Therefore in this study conducted on Hatay scale, it is tried to determine to what extent the functionality of five metropolitan areas such as authority, service, source, audit and coordination among the district municipalities of Hatay Metropolitan Municipality and Hatay. 


\section{GİRiş}

Büyük yerleşim yerlerinin daha etkin yönetilebilmesi ve bu şehirlerde yaşayan büyük nüfus kitlelerine verimli hizmet sunulabilmesi arayışları hemen her zaman gündemde olmuştur. Bugün büyükşehirlerle ilgili düzenlemeler, sadece yerel hizmet üretmemekte aynı zamanda gündelik hayatın da yeniden şekillenmesinde aktörel bir rol üstlenmektedir. Diğer bir ifade ile bu alanlarla ilgili yapılan bir düzenleme, sadece şehir yönetimlerini yapılandırmıyor, aynı zamanda genel yönetimi ve toplumsal sorunlara çözümleri de yeniden yapılandırıyor. Uygulamada olan 30 büyük şehre ek olarak telaffuz edilen ve oluşturulması planlanan 30 bütün şehir yapılanması da dikkate alındığında yapılan ve yapılacak olan düzenlemelerin, uygulamada sorunlardan çok çözümlerinin konuşulacağı bir sonucun görülebilmesi sağlanabilmelidir. Nitekim 6360 sayılı yasa ile büyük şehir belediyesi statüsünü kazanan yerlerde, bazı sorunlar çözüme kavuşurken bazı sorunlar da farklı şekillerde dile getirilmiştir. Aslında bu sorunların benzeştiği de söylenemez. Diğer bir ifade ile uygulamada farklı sorunlarla karşılanması büyük şehir statüsünü kazanan alanlarla da ilgili olabilmektedir. Ancak özellikle yetki, hizmet, kaynak, denetim ve koordinasyon sorunlarının bütün şehirlerde farklı şekillerde dile getirildiği söylenebilir. Aslında bu çalışma da 6360 sayılı yasa ile Büyük Şehir Belediye statüsü kazanan Hatay'ın, belirtilen bu sorunlarla ne ölçüde karşılaştı̆̆1 ve bu sorunların çözümlerinin neler olabileceğine odaklanmaktadır. Bu bağlamda çalışma ile Hatay Büyükşehir Belediyesi ile Hatay'daki ilçe belediyeleri arasındaki yetki, hizmet, kaynak, denetim ve koordinasyon gibi beş temel alanda işlevselliğinin hangi ölçüde sağlanabildiği tespit edilmeye çalışılmıştır.

\section{BÜYÜK ŞEHIR YÖNETIMLERININ YASAL VE ANAYASAL DAYANAĞI}

Büyük şehir yönetimlerine ilişkin ilk girişimin 1858 'de çıkarılan ve küçük birimleri birleştirip büyük şehir yapma yerine, büyük alanı bölüp aynı alanda farklı teşkilatlanmalar oluşturan bir büyük şehir modelini öngören bir nizamname ile yapıldığı belirtilir. Benzer bir yaklaşım, Kanun-i Esasiye dayanarak oluşturulan Dersaadet Belediye Kanunu'nda görülmüştür (Bulut, 1999:32-34). Cumhuriyet döneminde özellikle 1950 sonrası birtakım tasarılar da hazırlanmış olmakla beraber, büyükşehir yönetiminin Anayasal dayanağı 1982 Anayasası'nın 127. Maddesinde yer alan "Kanun büyük yerleşim merkezleri için özel yönetim biçimleri getirebilir" hükmüdür. Nitekim bu hükme istinaden 1984 yllında kabul edilen 195 sayılı Kanun Hükmünde Kararname (KHK) ve yine aynı yıl yürürlüğe giren 3030 sayılı Yasa ile büyükşehir belediye yönetimi kendi yasal statüsüne kavuşmuştur. 3030 sayılı Yasa'da büyükşehir kavramı "belediye sinırları içinde birden fazla ilçe bulunan şehirler" olarak tanımlanmıştır (md.3/1). Ayrıca yasada büyük şehrin adı ile bir büyükşehir belediyesi, büyük şehir dahilindeki ilçelerde ise ilçe isimlerini taşıyan "ilçe belediyeleri" kurulması hükme bağlanmıştır (md.4/1). Belediye yönetiminde 2 kademeli bir model oluşmuştur. Hızlı gelişen büyük şehirlerin sorunlarına daha kısa sürede çözüm getirmek yeni model arayışlarından geçmekteydi. İlçe kurulabilmesi yasa gerektirdiği için büyükşehir yönetimlerinin kurulma süreci zorlaşmaktaydı. Bu nedenle yeni kriterler geliştirildi. "Alt Kademe" ve "İlk Kademe" belediyeleri oluşturmak suretiyle yeni büyükşehir belediyeleri kurulma yoluna gidildi. 2004 y1lında 5216 sayılı Yasa kabul edilmiş, 3030 sayılı Yasa yürürlükten kalkmış, iki kademeli büyükşehir yönetim modeli bazı değişikliklerle birlikte devam etmiştir. 5216 sayılı Yasa 3030 sayılı Yasadan farklı olarak büyükşehir kurulabilmesi için 750.000 nüfus kriterini getirmiştir. Sadece İstanbul ve Kocaeli illerinde büyükşehir belediye sınırı, il mülki sınırı olarak belirlenmiştir. 2008 yılında yürürlüğe giren 5747 sayılı yasa, ölçek sorununu çözmeye ilişkin bir reform yapmayı hedeflemenin yanı sıra (Arıkboğa, 2008b:320-324) büyükşehirlerdeki büyük ilçeleri bölerek ya da küçük beldeleri birleştirerek yeni ilçeler kurmayı ve bu bağlamda alt kademede sadece ilçe belediyelerinin, üst kademe ise büyükşehir belediyesinin bulunduğu, daha sade bir idari yapıyı hedeflemiştir (Arıkboğa, 2013:61).

2012'de çıkarılan ve 2014 yerel seçimlerle hayata geçen 6360 sayılı yasa ise, özellikle etkinlik ve verimliliği artırma bağlamında bir takım köklü değişiklikler içermektedir. Genel anlamda bu değişikliklere bakılacak olunursa; Türkiye'de büyükşehir belediye sayısının 16'dan 30'a çıktığı, büyükşehir belediye sınırının il mülki sınırlarına taşındığı, büyükşehir belediyesi olan yerlerde ilçe belediyesi olma nüfus kriterinin 50.000'den 20.000'e düşürüldüğü ve bu ölçekte belde belediyelerinin ve il özel yönetimlerinin tüzel kişiliklerinin kaldırıldığı, nüfus kriterinin il nüfusuna çekilip 750.000'in üzerinde olması gerektiği görülmektedir. Ayrıca yerel düzeyde hizmet sunumunda etkinliği sağlamak amacıyla valilikler bünyesinde Yatırım İzleme ve Koordinasyon Başkanlıkları kurulmuştur. Bu birim, 1 Eylül 2016'da Kanunda yapılan düzenlemeyle kamu tüzel kişiliğine haiz ve özel bütçeli bir birime dönüştürülmüştür ki, değişiklikle valilik yeniden tanımlanarak yönetsel kapasitesi artırılmıştır (Akman ve Kalender, 2018:1030). Büyükşehir belediyelerine ilişkin veya onunla ilgili 
düzenlemeler dikkate alındığında, etkinlik ve verimliliği sağlayan bir yönetim ihtiyacı kendini göstermekle beraber, uygulamada bir takım sorunlarla karşılaşılmaktadır. İşte bu çalışma, 6360 sayılı yasanın uygulanmasında Hatay'da karşılaşılan temel sorunları irdeleyerek bir takım öneriler getirmektedir.

\section{6360 SAYILI YASA İLE GELEN BÜYÜKȘEHİR BELEDIYYE MODELİ}

6360 sayılı yasanın getirdiği model irdelenirken oluşabilecek bürokrasi ve personel sistemine dikkat çekenler olduğu gibi (Pank, 2016:909-916), Yerel Yöneticilerin Büyük Şehir algısının ne olduğu ve bu düzenlemenin nasıl bir etki oluşturacağını irdeleyenler de olmuştur (Bulut ve Karakaya, 2016:1-36). Ayrıca bu yasanın uygulamaya geçmesiyle, su ve atık hizmetlerinin nasıl yapılacağı bu konuda büyük şehir ve ilçe belediyelerinin nasıl bir rolü olacağı incelenmiştir (Hayırsever Topçu, 2015:86-121). Bazı saha çalışmalarında (Kuzılboğa Özaslan vd., 2014:215-235; Genç, 2014:1-29; Bulut ve Kara, 2013:267-286; Dik, 2014:75-102; Erat, 2016:8798; Eldem, 2016:83-97; Sadioğlu vd., 2017:95-119) belde belediyelerinin kapatılmasının, köylerin mahalleye dönüştürtülmesinin, dağlık alanların yönetilmesinin uygulamada nasıl bir etki bırakacağ tartışılmıştır. Yine bu düzenlemelerin büyükşehir yönetimlerinin mali yapısı ve gelirleri üzerinde nasıl bir değişiklik getirdiği, kaynak paylaşım sistemleri açısından ne gibi bir katkı ve değişim sağladığı tartışılmıştır (Önez Çetin vd., 2016:168-197; Yüksel, 2016:731-756). Bu çalışmalardan bir kısmında büyükşehir statüsünü kazanan illerde, uygulamada yasanın getirdiği etkiler de irdelenmiştir. Örneğin Genç'in (2014:1-29) çalışmasında bu yasanın Aydın üzerindeki etkileri, Karasu'nun (2013:1-17) çalışmasında da Şanlıurfa üzerindeki etkileri sosyal, kültürel, denetim, idari ve mali açılardan ortaya konulmaya çalışılmıştır. Dolayısıyla büyükşehir yönetimleri kurulduğu günden bu yana görev ve yetki paylaşımı başta olmak üzere planlama ve mali bölüşüm gibi pek çok konuda karşılaşılan sorunlar nedeni ile köklü değişiklikler yapılmak zorunda kalınmıştır (Canpolat, 2010:45). Bu değişikliklerin yanı sıra yansıma ve yeni arayışların bugün de sürdüğünü söylemek mümkündür.

6360 sayılı Yasa'nın gerekçesi, kamu yönetiminde etkililik ve verimliliği artırmak, vatandaşın artan beklentisini karşılamak ve onların yönetim sürecine daha fazla katılımını sağlamak, parçalı planlar yerine bütüncül planlar yapmak ve yönetsel kapasitesi düşük yerel yönetim birimlerinin sebep olduğu kaynak israfinı önlemek olarak belirtilmiştir (Karaarslan, 2013:139; Zengin, 2014:102). Ayrıca, ölçek ekonomilerinden yeterince yararlanılamıyor olması, mevcut sistemdeki kaynak israfı, küçük ölçekli birimlerin kendi sorunlarını çözme konusunda başarısız olmaları, planlamanın ve koordinasyonun sağlanamayışı ve mali kaynak yetersizliği bu yasanın çözüm üretmeyi hedeflediği diğer sorun alanlarıdır (Çelikyay, 2014:11). Bu sorun alanlarının çoğu kez tartışıldığg ve çözüm getirilmeye çalışıldığı söylenebilir.

Yeni bir model olarak düşünülen bu düzenleme önemli değişiklikler meydana getirmiştir. Daha önce kısmen verildiği gibi bu değişiklikleri şöyle belirtmek mümkündür;

- 14 il belediyesi daha büyükşehir belediyesi yapılmış, sayısı 30'a çıkan büyükşehir belediyelerinin sınırları il mülki; ilçe belediyelerinin sınırları bu ilçelerin mülki sınırları olmuş,

- 5747 sayılı Kanun'dan itibaren iki kademeli (büyükşsehir ve ilçe belediyesi) olarak kurulan ve işleyen mevcut büyükşehir belediye modelinde, 2.000 nüfus şartına bağlı kalmaksızın, bu ikili modelden dolayı yeni büyükşehir belediyesi sınırları içinde kalan 1.076 belde belediyesi ile 16.500 köy tüzel kişiliğini kaybetmiş ve mahalleye dönüşmüştür (Zengin, 2014:103).

- Büyükşehir Belediyesi olma koşulu, belediye nüfusunun 750.000 'i aşmış olması yerine, il nüfusunun 750.000 üzerinde olması biçiminde değiştirilmiş,

- Büyükşehir olan illere bağlı ilçelerin mülki sınırları içinde yer alan köy ve belde belediyelerinin tüzel kişiliği sona ermiş, köyler mahalle olmuş, belediyeler ise mahalleleri ile birlikte bağlı bulundukları ilçenin belediyesine katılmışlardır.

- 30 büyükşehir belediyesinde il özel idarelerinin tüzel kişiliklerine son verilmiş, kaldırılan il özel idarelerinin yerine bu illerde, valiliklere bağlı Yatırım İzleme ve Koordinasyon Başkanlıkları kurulmuştur. 


\section{6360 SAYILI YASA UYGULAMASININ DEĞERLENDİRILMESİ ÜZERINNE HATAY ÖLÇEĞİNDE YAPILAN ÇALIŞMANIN DEĞERLENDİRILMESİ}

Çok kültürlü ve antik bir kent olan Hatay, gerek nüfus yapısı ve profilleri, gerekse yüz ölçümü açısından yeni oluşturulan büyükşehirlerden belki de en ilginç olanıdır. Doğal bir bölümleme olarak da adlandırılan "dağın bu yakası", "dağın öbür yakası" gibi dağınık ve bağlantısız yerleşim alanı olması ve ilçeler arasındaki uzaklık, bu modelin uygulanmasında belki de beklenen pozitif yansımayı engelleyen bir unsur olarak değerlendirilebilir. Beş yıldır uygulanmakta olan mevcut yasaya ilişkin çok sayıda hem teorik çalışma yapılmış hem de yasa, alandaki uygulayıcılar tarafından zaman zaman değerlendirilmiş ve bu değerlendirmeler raporlanmıştır. Yapılan araștırmaların birçoğunda benzer problemlere vurgu yapılmıștır. Bu çalıșma ile de özellikle yetki, hizmet ve kaynak dağılımı, koordinasyon ve denetim konularında yaşanan sıkıntıların bu beş yıllık süre zarfında aşılıp aşılamadığı ortaya konmaya çalışılmıştır.

\subsection{ARAŞTIRMANIN AMACI VE ÖNEMI}

Çalışmada Hatay ölçeğinde, Hatay Büyükşehir Belediyesi ile Hatay'daki ilçe belediyeleri arasındaki yetki, hizmet, kaynak, denetim ve koordinasyon gibi beş temel alanda karşılaşılan sorunlar ve bu sorunların ilçe belediye yöneticileri tarafından nasıl algılandığı tespit edilmeye çalışılmıştır. Araştırmanın amacı mevcut sorunları gidermeye yönelik çözüm önerileri ortaya koymaktır.

\subsection{ARAŞTIRMANIN EVRENİ VE YÖNTEMI}

Araştırma, Hatay ilinde büyükşehir alanındaki 10 ilçe belediye yöneticisi ( belediye başkan ve belediye başkan yardımcıları) ile derinlemesine mülakat yapılarak gerçekleştirilmiştir. Görüşmelere temel oluşturan ölçek, açık uçlu soruların yer aldığ "Yarı Yapılandırılmış Görüşme Formu" dur. Mevcut sorularla birlikte, daha ayrıntılı bilgi almak amacıyla ek sorular da yöneltilmiştir. Yapılan görüşmeler yirmi ile kırk dakika arasında sürmüştür, görüşmelerde ses kayıt cihazı kullanılmıştır. Katılımcıların bir kısmı kayıt alınmasını istemedikleri için verilen cevapların not edilmesi yolu tercih edilmiştir.

Veriler analiz edilirken ilkin görüşmeler yazılı olarak kaydedilmiştir. Verilerin kodlanması ve elde edilen bulguların yorumlanması yolu izlenmiştir. Aynı zamanda bulgular tablolaştırılmış ve ortaya çıkan tablolar yorumlanmıştır.

\subsection{ARAŞTIRMANIN KAPSAMI VE SINIRLILIKLARI}

Alan araştırması büyükşehirde yer alan ilçe belediye yönetimlerini kapsamaktadır. 31 Mart 2019 Yerel Seçimlerinin yaklaştığı bir zaman diliminde bu çalışma yapıldığı için, bu dönemdeki belediye başkanlarına ulaşmak ve randevu almak araştırmanın en önemli sınırlılı̆̆ını oluşturmuştur. Bir başka sınırlılık ise, yine aynı nedenle, başkanların söyleyecekleri her sözün kendi aleyhine dönebileceği endişesi olmuştur. Yöneltilen sorular araştırmanın diğer bir sınırını oluşturmaktadır. Kullanılan soruların konuyu değerlendirme açısından yeterli olduğu düşünülmektedir. Soruların araştırmaya katılanlar tarafından tam olarak anlaşıldığı ve samimiyetle cevaplandı̆̆ varsayılmaktadır.

\subsection{MÜLAKATLARLA ELDE EDILEN VERILERIN ANALIZİ}

Yapılan görüşmeler sonucunda elde edilen veriler ilk olarak yazıya dökülmüş sonra konu başlıkları ile birlikte verilen cevaplara göre sınıflandırma yapılarak betimsel analiz ve tablolama yöntemleri ile çözümlenmiştir. Görüşmelerin tarafsız bir biçimde ortaya konulabilmesi için çoğu zaman doğrudan alıntılara yer verilmiştir. Görüşmeye katılan İlçe Belediye Başkanları İBB-1 ile İBB-3 arasındaki numaralarla, İlçe Belediye Başkan Yardımcıları İBY-1 ile İBY-7 arasındaki numaralarla kodlanmıştır. Kodlama yönteminin tercih edilmesinin sebebi, araştırmaya katılanların kişisel bilgilerinin verilmesini istememeleridir. 


\subsubsection{Yetki Paylaşımı}

Katılımcılara, "Sizce büyükşehir belediyesi ile ilçe belediyeleri arasında sağlıklı bir yetki paylaşımı yapılmıș mıdır?", "Yeniden bir yetki paylaşımı yapılacak olsa bu paylaşımda kriterler neler olmalıdır?" ve "Büyükşehir yönetimleri ilçe belediyelerine hangi yetkileri bırakmalıdır?" soruları sorulmuştur. Katılımcılardan alınan yanıtlar şu şekilde olmuştur:

- İBB-1: "Kanun yetki paylaşımım esaslarını belirtmiş. Birçok yetki, mezarlık hizmeti gibi, otopark hizmeti gibi, yol yapım hizmeti gibi hizmetleri büyükşehir belediyesine devretmiş, daha sonra denmiş ki; ihtiyaç görülmesi halinde ve büyükşehir belediye başkanı ile ilçe belediye başkanlarının anlaşması halinde birtakım yetkiler ilçe belediyelerine birakılabilir ancak anlaşmazlık olduğu takdirde de çözüm merci büyükşehir belediye meclisidir denmiş. Mesela otopark, mezbahane ve mezarlı hizmetleri konusunda ilçe belediyesi yetkili olsun diye meclis kararı alındı, daha sonra büyükssehir belediyesi bunun doğru olmadı̆̆ını iddia ederek bölge idare mahkemesine gitti ve mahkeme de yürütmeyi durdurma kararl verdi. Ancak mahkemenin bu hizmetleri bize vereceğini düşünüyorum.

Bugün yaşadığımız en büyük bir diğer sıkıntıdan bahsedecek olursam; büyükşehir kapsamına alınan illerin tamamında ilk beş yıl önce 1/100.000'lik üst ölçekli plan yapılmak üzere peşinden 1/25.000'lik, 1/5000'lik ve 1/1000'lik planlart yapma gibi bir mecburiyeti var. Ancak sadece 1/100.000'likler bitirilebildi ve bu konuda şikayetler devam ediyor. Bütün ilin tek elden planlanmast ve imar planlarında da bütünlük sağlanması amaçlanmıştır.

Denetim mekanizması işlevsel hale getirilmelidir. Yapılması gerekenler yapılmadığında cezai müeyyide uygulaması değil, yaptırllmasının yöntemleri aranmalıdır".

- İBB-2: "Sağllkll yetki paylaşımı yeterince olmamıştır. Bazı konular hem büyükşehir hem de ilçe belediyeleri yapabilir diye ortaya bırakılmıstır. Ortaya bırakılan bu konularda mecliste karar alma söz konusu olduğunda da hep bir çatışma yaşanmaktadır. Hangi işleri ilçe belediyeleri hangi işleri büyükşsehrin yapacă̆ı net bir biçimde yazılması gerekmektedir. Kriter mutlaka belirlenmelidir. Büyük ilçeler ile küçük ilçeler aynı kotaya bırakılmaktadır. Bu bağlamda nüfus kriteri mutlaka dikkate alınmall. Diğer taraftan belediyelerin temel görevlerinden biri imar planlarını hazırlamaktır. Bu konuda 1/100.000, 1/25.000 ve 1/5000'lik nazım imar planlarını büyükşehrin yapması gerekiyor. Bu yapılmadı̆̆ında herhangi bir müeyyide yok. En temel olan bu görevini bile sağllkl yapmayınca bu şehirlerin gelişiminde büyük bir sorun teşkil ediyor. Yerine getirilmeyen görevler için cezai yaptırımlar olması gerektiğini düşünüyorum".

- İBB-3: "Kesinlikle yapılmamıştır. Hatta yetki karmaşası yaşanmaktadır. Özellikle zabıta hizmeti ile ilgili görevlendirmelerde (ilçenin de zabitası var büyükşehrin de) ve mezarlık hizmetlerinde büyük sıkıntılar yaşanmakta. 4,5 yıl oldu ancak sikıntılarımız azalmadı̆̆ gibi fazlasıyla arttı. Büyükşehir metropolü yönetmeli, alanı ilçe belediyelerine bırakmalılar. Büyükşehrin kırsal alana yetişmesi gerçekten çok zor olmaktadır. Arazi yolu, mezbaha yolu, köy içi yollar, mezarlıkların bakımı, onarımı, yapımı gibi taleplerin tamamı ilçe belediyesine geliyor. Bununla ilgili yetkimizin ve ödeneğimizin olmaması bizleri çok sıkıntıya düşürüyor. Vatandaş büyükşehre gittiğinde de muhatap bulamiyor".

- İBY-1: "Bu kanundaki en büyük sıkıntı zaten bu. Tüm yetkinin ve bütçenin büyükşehir belediyelerinde olmast ilçe belediyelerinin şuan en büyük sorunudur. Vatandaşın sorununa çare olamiyorsunuz bu da ilçe yöneticilerini zora sokuyor".

- İBY-2: "Yapılmadiğını düşünüyorum. Halk yasayı bilmediği için muhatap olarak direk bizi görüyor, oyunu kime verdiyse hizmeti de ondan bekliyor haklı olarak, yasa değişmeli, bütünüyle olmasa da bazı önemli konularda tekrar ilçe belediyeleri yetkilendirilmelidir ve o doğrultuda da bütçesi olmalıdır".

İBY-3, İBY-4, İBY-5, İBY-6 ve İBY-7 de yetki konusunda sıkıntıların olduğunu ifade etmişlerdir. Katılımcıların tamamı imar planlarının hazırlanma sürecinin de olması gerektiği gibi işlemediğini, henüz planların tamamlanamadığını, bu konu ile ilgili tekrar bir düzenleme yapılmasına ihtiyaç olduğunu belirtmişlerdir. İBY-6, tekrar bir yetki paylaşımı yapılacaksa nüfusun ve yöresel farklılıkların da dikkate alınması gerektiğini ayrıca ifade etmiştir. 
Tablo 1. Yetki Paylaşımı

\begin{tabular}{|l|l|}
\hline Ortak İfade / Sorunlar \\
\hline - İmar Planlarının tamamlanma sürecine ilişkin sıkıntıların varlığı ve bu konudaki yetkilerin farklı \\
belediyelerde olması (1/1000'lik ve $1 / 5000$ 'lik planlar). \\
- $\quad$ Bazı hizmetler için her iki belediyenin de yetkili olabilmesi ve yaşanan yetki karmaşası. \\
- $\quad$ Sorumluluklar yerine getirilmediğinde herhangi bir yaptırımın olmaması \\
\hline Öneri \\
\hline - İmar Planlarını hazırlama yetkisine ilişkin tekrar bir düzenleme yapılmalı \\
- Tüm yetkiler belirlenirken nüfus bir kriter olmalı, merkeze uzaklık dikkate alınmalıdır \\
- Otopark, mezarlık, köy yollarının onarımı gibi hizmetleri sunma başta olmak üzere temel \\
birtakım yetkiler sadece ilçe belediyelerinde olmalı \\
\hline
\end{tabular}

Kaynak: Yazarlar tarafından hazırlanmıştır.

Tablo 1'de de ifade edilmeye çalışıldığı üzere, büyükşehir belediyesi ile ilçe belediyeleri arasında yaşanan temel sorunun aslında yetki karmaşasından kaynaklandığı ileri sürülebilir. Yetki alanları ve tanımlamaları net bir şekilde belirlenmelidir çünkü bazı hizmetler hem büyükşehir belediyesi hem de ilçe belediyeleri tarafından yapılabilir diye arada bırakılmıştır. Bu konularda, mecliste karar alma söz konusu olduğunda da çatışma yaşandığı ifade edilmiştir.

\subsubsection{Sunulan Hizmetler}

Kat1lımc1lara , "Büyükşehir ölçeğinde ilçelere götürülen hizmet konusunda adil bir dağıllım olduğunu düşünüyor musunuz?" sorusu sorulmuş ve bu konuda da benzer yanıtlar alınmıştır. Alınan yanıtlar şu şekildedir;

- İBB-1: "Kanundan kaynaklı değil ancak uygulama noktasında sıkıntılar var ve büyükşehir belediyesi tüm ilçelere eşit mesafede duramıyor maalesef. Bunun da tabi hem kişisel hem de siyasi nedenleri olduğu açıkça ifade edilebilir. Örneğin kanun büyükşehir olan illerde öncelikli olarak altyapı ve imar sorunlarının çözülmesi gerektiğini söylüyor. Bizler bu temel konularda bile çok sıkıntı yaşlyoruz. Konuyla ilgili ihmal hatta görevi kötüye kullanma bile söz konusu olabiliyor".

- İBB-2: “Adil bir dăğllım kesinlikle yok, tamamen sübjektif bir şekilde ve siyasi kaygılarla karar veriliyor. Önceden gerek bütçe gerekse ilçelere götürülecek hizmetler bakımından taahhüt ettiği projeleri yapıp yapmamak tamamen büyükşehir belediye başkanına bağll. Çeşitli gerekçelerle bunlardan vazgeçip sözünü verdiği hizmetleri başka ilçelere kaydırma durumu da ortaya çıkabiliyor. Siyasi kaygılarla ve keyfi hareket edilebiliyor ve ilçelerin büyükşehir bütçesinden aldığ paylarda da adalet söz konusu değil. Büyükşehre İller Bankası ödeneğinden \%30 pay aktarllyyor, \%10'u HATSU yani su ve kanal payı aktarllyyor, bir de ilçelere otopark hizmeti için yapılması gerekip de yapılmayanlarla alakalı inşaat ruhsatlarına otopark bedeli ödeniyor. Bunu da ilçe belediyeleri tahsil edip, büyükşehir belediyesinin hesabına yatırıyor. İlçeler görevlerini kanuni olarak yerine getiriyor. Büyükşehir de ilçelerden aldı̆̆ bu payları ilçelere yatırım olarak döndürmesi gerekirken, ilçelerden toplanan paralar diğer ilçelerin yatırımlarına aktarlliyor. Bu da hizmet sunumunda adil olunmadı̆gın gösteriyor. Mevzuatta bu konuyla ilgili bir düzenleme yapılmalı ve bu şekilde ilçelerden alınan paraların aynı ilçelere yatırım olarak dönüşü sağlanmalıdır. Kanunda bu konuyu kontrol altında tutacak bir maddenin bulunmamasını da hiç etik değildir".

- İBB-3: “Adil bir dă̆ıllım olmadığını düşünüyorum. Her şeyden önce büyükşshir belediyesi merkeze uzak olan ilçeleri çok önemsemiyor ve taleplerimizi yerine getirmekten daha başında kaçınıyor. Bunu hem zaman kaybı hem de kaynak israfi olarak görüyor. Benim ilçemde tasarladı̆̆ım planı, imarı büyükşehir gündeme almaz ise yaptırma imkân ve ihtimalim yok çünkü ben sadece talep edebiliyorum. Payların bölüşümünde adil olunmuyor. Nüfusu az olan ilçeler daha fazla ödenek alabiliyor ya da tam tersi de yaşanabiliyor. İlçe belediyesine gelen kaynağın 
\%30'u doğrudan büyükşehre, \%10'u da HATSU İdaresi'ne gönderiliyor. İlçe belediyesinin İller Bankasından gelen dışında herhangi bir geliri yok. Sadece çevre temizlik vergilerinin \%80’i ilçe belediyesinin, \%20'si büyükşehrin. Ancak biz bunu da henüz alamadık. Büyükşehir örneğin ilçeye su ile ilgili yaptığı herhangi bir çalışmayı gerekçe göstererek bu paranın da oraya aktarıldı̆̆ıı söylüyor”.

- İBY-1: "Hayır olmadiğın düşünüyorum. Özellikle bu konunun meclis toplantılarında defalarca tartışılmasına rağmen yine de bir ilerleme kaydedilememiştir. Büyükşehir belediyesi özellikle merkeze uzak ilçelerin sorunlarıla çok ilgilenmiyor ve taleplerimizi de dikkate almıyor zaten".

- İBY-2: "Kesinlikle adil bir dăğllm yok. İlçelerde ihtiyaç duyduğumuz hizmetlerin gündeme alınıp alınmaması tamamen büyükşehre ve başkanına bağll. $O$ da kişisel veya siyasi düşünüp keyfi hareket edebiliyor ve genelde de böyle oluyor zaten".

- İBY-3: "Hayır yok. Örneğin ilçelerde acil sonuçlanması gereken konulardan biri, özellikle vatandaş açısından, ruhsatlandırma işlemleridir. Ruhsat ile ilgili her iş bizde bitiyor, yetkili ilçe belediyesi ancak son olarak yapılacak olan numarataj büyükşehir belediyesinde. Büyükşehir sadece kapı numarası verecek ve bu çok basit olan iş bile aylarca bekleyebiliyor, vatandaşı oraya yönlendirdiğimizde de muhatap bulamadan geri geliyor. Bu tip ayrintıl işlemlerle ilgili düzenlemeler yasada tekrar gözden geçirilmelidir".

İBY-4, İBY-5, İBY-6 ve İBY-7 de benzer ifadelerle adil bir dağılım olmadığın, kişisel veya siyasi çıkarların bu dağılımda büyük rol oynadıklarını belirtmişlerdir.

Tablo 2. Sunulan Hizmetler

\begin{tabular}{|l|}
\hline Ortak İfade / Sorunlar \\
\hline - $\quad \begin{array}{l}\text { Yasanın uygulanmasına ilişkin sübjektif kriterler olmaması, siyasi nedenler dikkate alınarak } \\
\text { ilçelere ihtiyaç duyulan hizmetin gitmemesi } \\
\text { — İlçelerden alınan payların tekrar ilgili ilçelere yatırım olarak dönmemesi }\end{array}$ \\
\hline Öneri \\
\hline - Yasada tekrar bir düzenleme yapılarak ilçelerden alınan payların aynı ilçelere yatırım olarak \\
dönüü sağlanmalı ve bu kontrol altına alınmalı \\
\hline
\end{tabular}

Kaynak: Yazarlar tarafından hazırlanmıştır.

Tablo 2'ye ve katılımcılardan alınan yanıtlara bakıldığında ilçelere götürülen hizmetlerde adil olunmadığı görülmektedir. Büyükşehir belediyesi ilçelerdeki öncelikli sorun alanlarını tespit ve çözüm noktasında yeterli görülmemektedir.

\subsubsection{Denetim}

Katılımcılara, "Yerel ölçekte denetimlerin nasıl olması gerektiğini düşünüyorsunuz?", sorusu sorulmuş ve alınan yanıtlar şu şekilde olmuştur;

- İBB-1: “Büyükşehirlerde ylllık denetimler ilgili kurumlar tarafindan yapılır zaten (Saylştay Denetimi ve Mülkiye Müfettişleri tarafindan yapılan denetim). Denetimlerin neticesinde, tespit edilen eksiklikler ve slkıntılar için çok da fazla bir şey yapılmadl. Ancak bu konuda daha önce de belirttiğim bir husus vardl, denetim mekanizmasının, yapılması gerekenler yapılmadığında cezai müeyyide uygulanması değil, yaptırllmasının yöntemleri aranarak işlevselliğ $i$ sağlanmalıdır. Yapılmayanlar yaptırılıp bütçesi alınmak suretiyle sorunlar çözümlenmelidir. YIKOB (Yatırım İzleme ve Koordinasyon Başkanlıkları)'ların görevini hakklyla yerine getirmesi gerektiğini düşünüyorum. Burada da valiler bunun siyasi iradeye müdahale olacă̆ın düşünülerek yapılmıyor”.

- İBB-2: "Her yll büyükşsehre iki kademede denetim gelir birisi Sayıştay Denetimi (Harcamalar Kontrol Amaçli) bir de Mülkiye Müfettişleri tarafindan yapılan denetimdir. Belediye yönetiminin kanuna uygun çalışıp çalışmadı ̆̆ kontrol edilir. Bu denetimler yapıldığı halde mevcut eksikliklerin giderilmesi söz konusu olmadl. Mesela yapılan ihale sisteminde İhale Kanunu aşırı derecede zorlanıyor ve bu kanunun dışında açık eksiltme ihalesi ile yani açık ihale 
modelleri yapılmak yerine türlü Kanunun 21. Maddesi kullanılarak davetiye usulü ya da belli istekliler arasında davet edilerek, acil afet durumunda yapılması öngörülen ihaleleri, böyle bir durum olmamasına rağmen yapıyorlar. Hizmette de borçlanma yolu tercih edilerek yatırım yapma yoluna gidiliyor. İște bu yüzden denetimler yapıldıktan sonra hukuki süreç bağlamında karşılık bulması lazım, görevini iyi yapanlar ile yapmayanlar arasında hukuki yaptırım bakımından hiçbir fark olmadĭ̆ını düşünüyorum. Kanunda çerçeveyi belirleyecek objektif kriterlerle ilgili bir hüküm yok. Yaşanan sıkıntılarla ilgili olarak Meclis Denetim Komisyonu tarafindan raporlanma yapllır ve her yll bu konular meclis gündemine getirilip kayıt altına alınır. Ancak meclisin icra noktasında veya yaptırım konusunda yetkisinin olmayışı nedeni ile mecliste alınan kararların da bir önemi kalmiyor".

- İBB-3: "Sayıştay denetiminde özellikle fiyatlandırma konusunda ciddi sıkıntılar yaşanabiliyor. Hepimizin bildiği gibi usulsüzlüklerin rahat yapılabildiği yerler belediyelerdir. Bir de kendi denetim komisyonumuz var mecliste ancak bu komisyonu bilgi anlamında yeterli bulmuyorum. Ayrıca insanların kendi kendini denetlemesi çok da doğru değildir. Ben ekonomik ve mali bir denetim birimi oluşturulması gerektiğini düşünüyorum. Yine Iç IŞsleri Bakanlığı veya Çevre Şehircilik Bakanlı̆̆ bünyesinde oluşturulabilir”.

- İBY-1: "En büyük sıkıntılardan bir tanesi budur. Baktı̆ıınızda evet denetimler yapıllyor her yıl belli dönemlerde müfettişler ve Saylştay'dan geliyorlar. Ancak bu denetimler kanun gereği bir formaliteyi yerine getirmiş olmak için yapıllyor gibi algıllyoruz. Çünkü şimdiye kadar bu denetimlerde tespit edilen sıkıntıları ortadan kaldırmak için kimsenin bir adım attı̆̆ını görmedik".

- İBY-2: "Denetimler yapilyyor düzenli olarak fakat bunların sonuçlart ile ilgili herhangi bir bilgimiz olmad şuana kadar".

- İBY-3: "Sadece belediyeler değil tüm kurumlarda önem verilmesi gereken konu denetimdir. Denetimler ne kadar doğru gerçekleştirilirse insanlar o oranda yanlış yapmaktan uzaklaştırırsınız. Maalesef bizdeki en büyük sıkıntılar denetimlerin yeterli olmamasıdır. Yapılan denetimler de yasa gereği yapılıyor, yapılmak zorunda olduğu için yapıllyor ancak sonuçları nerede ya da tespit edilen aksaklıkları gidermeye yönelik yapılan bir şeyler var mı bilmiyoruz. Ben görmedim henüz".

- İBY-4: "Mevcut denetim sisteminde bir sıkıntı olduğunu düşünmüyorum ancak doğru, amacına uygun denetimler yapılmıyor diye düşünüyorum. Denetimler neticesinde tespit edilen sıkıntılarla ilgili herhangi bir ceza sistemi yok".

- İBY-5: "Denetimler yapıllyor aslında ancak sadece yasa gereği yaptlyor. Bununla ilgili ayr bir birim oluşturulabilir, sadece belediyelerde denetimden sorumlu bir birim. Görevini hakkiyla yerine getirecek bir birim olmal. Aslında valilikler bünyesinde oluşturulan YIKKOB'lar bu amaca hizmet etmeliydi fakat o birim de işlevsel hale getirilemedi".

İBY-6 ve İBY-7 de konuyu, diğer katılımcılara benzer biçimde değerlendirmişlerdir. Belediyelerdeki denetim konusundaki yetersizlikler hususunda tüm katılımcılar aynı görüşleri dile getirmişlerdir.

Tablo 3. Denetim

\begin{tabular}{|l|}
\hline Ortak İfade / Sorunlar \\
\hline - \\
— \\
\hline Önenetimlerde tespit edilen sıkıntıların giderilmemesi \\
\hline - Yapılırımların olmaması geya uygulanmaması \\
- YİKOB' lar görevini hakkı ile yerine getirmeli \\
- Özel olarak bakanlık bünyesinde Denetim Birimi oluşturulmalı \\
\hline
\end{tabular}

Kaynak: Yazarlar tarafından hazırlanmıştır. 
Katılımcılardan alınan yanıtlar değerlendirildiğinde Tablo 3'de de belirtildiği gibi aslında denetim konusunda ciddi aksaklıklar yaşandığı ifade edilebilir. Cezai müeyyidelerin olmayışı sıkıntıların devam etmesine neden olmaktadır. Yılda iki kez gerçekleştirilen denetimlerin aslında sadece yasa gereği yapıldığı hususunda da katılımcılar hemfikirdir. Diğer taraftan bu amaç için kurulan Yatırım İzleme ve Koordinasyon Başkanlığı da kuruluş amacına uygun hareket etmemekte veya edememektedir. Bu birimin de daha işlevsel çalışması sağlanmalıdır ya da tamamen ayrı olarak bakanlık bünyesinde yeni bir denetim birimi oluşturulmalıdır.

\subsubsection{Koordinasyon}

"Sizce büyükşsehir belediyesi ile ilçe belediyeleri arasında koordinasyon sağlanabiliyor mu?", sorusuna katılımcılardan alınan yanıtlar şöyle olmuştur;

- İBB-1: "Kesinlikle sağlanamıyor. Ve kanun kabul edilip uygulanmaya başladiğ ilk zamanlar bu durumu geçiş aşaması olmakla açıklayabiliyordunuz fakat üzerinden neredeyse 5 yıl geçti hala bir arpa boyu yol alınmadı maalesef. Öncelikle bunun sebebi merkezden uzak oluşumuz daha sonra ve astl sebebi de yetkililerdir. Bu konuda da genelde personel suçlaniyor, buna katılmıyorum çünkü çalışan personel siz ne talimat verirseniz o yönde hareket eder ve zaten yerine getirir. Koordinasyonun sağlanması için büyükşehir belediyesi bünyesinde kurulan Alt Yapı ve Koordinasyon Merkezi' nin de gerçekten ne yaptığını bilmiyoruz. AYKOME' lerin asıl görevlerini yerine getirecek biçimde tekrar düzenlenmesi gerektiğini düşünüyorum”.

- İBB-2: "Koordinasyon ile ilgili gerçekten büyük sıkıntılarımız var. Büyükşehirler kurulurken büyük öneme sahip olan AYKOME dediğimiz Alt Yapı Koordinasyon Merkezi'nin sadece ismi var. Burada alt düzeyde 22 tane birim var. Bunlartn zaten 14 tanesi büyükşehirde çalışan daire başkanları gibi kişilerden oluşmakta. Kalanlar da altyapı kuruluşlarının ilçeyi belediyede temsilen ve her birinin 1 oy hakk bulunan, başkanın görevlendireceği kişilerden oluşmakta. Dolayısıla burada büyükşsehir belediyesinin istemediği bir kararın, diğer kurumların tamamı bir araya gelse bile alınması söz konusu değil, böyle bir güce sahip değiller. Oy çoğunluğu zaten büyükssehir belediyesinde. 4,5 yll geride bıraktık ve sıkıntılar azalmadığ gibi her geçen gün de artmaktadır. Her bir yatırımcı kazı bedelini yatırmasına müteakip aldığ yetki ile yani kazı izin belgesi ile kazı faaliyeti yapabiliyor bu da şehir de sıkıntılara neden oluyor. Oysaki yasa, AYKOME ile ilgili tam bir yetki vermiş. Yapılması öngörülen plana sadık kalmayan yatırımcı kuruluşa ceza kesebilme yetkisi var ve yatırımcı kuruluş yeterince bütçe ayıramıyorsa bunun bedelini büyükşehir belediyesi karşılayıp, ilgili kuruluştan fazlasılyla tahsil etme yetkisi de var, bu yasada mevcut ama bu maddelerin hiçbiri kullanılmıyor. Dolayısıyla alt komisyonlar ve ilgili diğer birimler işlevsiz kallyor".

- İBB-3: "Zaten mevcut sorunların çözülememesinin veya sürecin uzamasinin nedenlerinden bir tanesi de koordinasyon sorunu diye düşünüyorum. Özellikle bizim gibi merkezden oldukça uzak olan ilçeler için bu daha fazla söz konusu. Çünkü birçok konuda büyükşehir belediyesi yetkili kılındığ iç̧in biz vatandaşı sürekli oraya yönlendirmek durumunda kalıyoruz. Hem nitelikli, mevzuatı ve uygulamayı bilen personel eksikliği hem de olması gereken birimlerin olmaması sorunları daha da çözümsüz hale getiriyor. Büyükşehirde bir koordinasyon merkezi var ancak açıkçası o merkez ne yapıyor bilmiyoruz".

İBY-1, İBY-2, İBY-3, İBY-4, İBY-5, İBY-6 ve İBY-7 de büyükşehir belediyesi ile ilçe belediyeleri arasındaki koordinasyonun sağlanamadığını ifade etmişlerdir. İBY-4 ve İBY-7 diğer katılımcılardan farklı olarak, AYKOME' lerin çalışma usulü ve birimin kendisi ile ilgili ilçe belediyeleri personeli ile bilgi paylaşımında bulunmaları ve ilgili birimle yapılabilecek iş ve süreçler konusunda sorumlulukların sınırını bilmek adına bilgilendirilmeleri gerektiğini belirtmişlerdir. 
Tablo 4. Koordinasyon

\begin{tabular}{|l|}
\hline Ortak İfade / Sorunlar \\
\hline - AYKOME' nin görevini sağlıklı yapmaması \\
- Alt komisyonların birimlerle bilgi paylaşımında bulunmaması \\
- Nitelikli personel sıkıntısı \\
\hline Öneri \\
\hline - AYKOME' nin işlevselliği sağlanmalı \\
- AYKOME yasadan aldığı yetkiyi kullanmalı, yasa uygulayıcıları da mevcut yasaya hakim \\
olmalı ve personelini bu doğrultuda yönlendirmeli
\end{tabular}

Kaynak: Yazarlar tarafından hazırlanmıştır.

Tablo 4'de görüldügü üzere büyükşehir ve ilçe belediyeleri arasında yaşanan koordinasyon sorunu ilgili birimin ve komisyonların işletilememesinden kaynaklanmaktadır. Buna bağlı olarak yetkili kişilerin ve personelin yasanın uygulanması hususunda bilgi eksikliğinin bulunması da nedenler arasında sayılabilir.

\subsubsection{Kaynak Sorunu}

Katılımcılara, "Büyükşehir ve ilçeler arasında kaynak bölüşümünde ne gibi sorunlar var, önceki durumla kıyas yapsanız özellikle belirtmek istediğiniz hususlar neler olur?", sorusuna alınan yanıtlara bakıldığında bütün katılımcılar aslında 6360 sayılı Yasa ile gelen en büyük sıkıntının kaynak sorunu olduğunu ifade etmiş̧lerdir. Çünkü büyükşehir belediyeleri dün ile bugün arasında 2,5 kat artan kaynağa sahip olmuşlardır. Bu da ilçe belediyelerinin ellerinden kaynaklarının alınıp büyükşehir belediyelerine devredilmek suretiyle yapılmıştır. Payların bölüşümünde dikkate alınması gereken nüfus kriteri göz ardı edilmiştir. Kaynağı olmayan bir belediyenin hizmet sunmasının da beklenemeyeceği ve yeniden bir düzenleme ile kaynakların ilçe lehine artırılması gerektiği belirtilen diğer bir husus olmuştur. Özellikle kaynakların ilçe belediyeleri paylarından büyükşehir belediyelerine aktarılan \%30'luk oranın çok fazla olduğunu, bu payın azaltılması gerektiğini ifade etmişlerdir.

Tablo 5. Kaynak Sorunu

\begin{tabular}{|l|}
\hline Ortak İfade / Sorunlar \\
\hline • İlçe belediyelerinin kaynaklarının büyük ölçüde büyükşehir belediyelerine aktarılmış olması \\
• Kaynak sıkıntısı nedeni ile hizmet sunumunun olumsuz yönde etkilenmesi \\
\hline Öneri \\
\hline - İlçe belediyelerinin kaynakları artırılmalı \\
- Büyükşehirden ilçelere aktarılması gereken kaynakların tahsili bir yaptırıma bağlanmalı
\end{tabular}

Kaynak: Yazarlar tarafından hazırlanmıştır. 


\section{SONUÇ VE DEĞERLENDİRME}

$\mathrm{Bu}$ çalışma ortaya koymaktadır ki, yetki paylaşımı ile ilgili sorunların başında, yasada yetki tanımlamalarının açık bir biçimde yapılmaması gelmektedir. Bazı hizmetlerin yerine getirilmesinde hem büyükşehir belediyesi hem de ilçe belediyelerinin sorumlu olması, yetki karmaşasına neden olmaktadır. Sunulan hizmetlerle ilgili olarak, yasanın uygulanma noktasında objektif kriterlerin bulunmaması, hizmet sunumunda her bir belediyenin farklı yaklaşım sergilemesi başta olmak üzere, ilçe belediyelerinin yerine getirmesi daha doğru ve uygun olan bir birtakım temel hizmetlerin büyükşehir belediyelerinin yetkisine bırakılması bu konudaki sorunların temelini oluşturmaktadır. Denetim konusunda yaşanan en büyük sorun, yanlış uygulanan veya yerine getirilmeyen hizmetlerin cezai müeyyidesinin olmamasıdır. Koordinasyon konusunda yaşanan temel sorun, bu iş için oluşturulun ilgili birimin (AYKOME - Alt Yapı Koordinasyon Merkezi) görevini sağlıklı yapmamasıdır. Kaynak sorunu, ilçe belediyelerinin kaynaklarının büyük bir bölümünün büyükşehirlere aktarılmasıdır.

Yapılan alan araştırmasından elde edilen bulgular, 6360 sayılı Yasa'nın büyükşsehir belediyesi ile ilçe belediyeleri arasındaki ilişkiler bakımından sıkıntılar içerdiğini göstermektedir. Yasanın ortaya çıkış amacı ölçek büyütme yolu ile hizmetlerin tek elden yürütülmesi, bu şekilde etkin ve verimli hizmet sunumunun gerçekleştirilmesidir. Ancak yasadaki düzenlemelerin sınırlarının net bir şekilde belirlenmemiş olması farklı yorumlanmasına ve uygulama konusunda aksaklıklara neden olmaktadır. Siyasi görüş farklılıkları, büyükşehir belediyesi ile ilçe belediyelerinin farklı partilerden olması zaman zaman özellikle kentin kırsalına sunulan hizmetlerde farklı uygulamalara neden olmaktadır. Benzer sonuçlar farklı ölçeklerde yapılan araştırmalarda da ortaya konmuştur.

Uygulama noktasında yaşanan sıkıntılar göz önünde bulundurulduğunda 6360 sayılı yasada özellikle ilçe belediyeleri lehine revizyon zorunlu hale gelmiştir. Başlarda hizmet sunumunda yaşanan aksaklıklar geçiş aşaması olması ile açıklanabiliyorken, bugün gelinen noktada uygulanmakta olan yasa, hizmet sunumunda etkinlik ve verimliliği istenilen düzeyde sağlayamamaktadır. Genel olarak değerlendirmek gerekirse, Hatay'da büyükşehir ile ilçe belediyeleri arasındaki yetki, hizmet, kaynak, denetim ve koordinasyon konularında tam bir etkinlik sağlandığı ve işlevsel bir yönetim gerçekleştiği söylenemez.

\section{KAYNAKÇA}

AKMAN, Çiğdem ve KALENDER, Mustafa (2018), "Yerelde Yeni Bir Merkezi Yönetim Birimi: Yatırım İzleme ve Koordinasyon Başkanlı̆̆ı", Ankara Üniversitesi SBF Dergisi, S.73(4), ss.1025-1056.

ARIKBOĞA, Erbay (2008), "Yerel Yönetimler ve Organları: Organlar Arası İlişkilerin Üç Boyutlu Analizi", Türkiye'de Yerel Yönetimler (Ed. Recep Bozlağan - Yüksel Demirkaya), Nobel Yayınları, İstanbul, ss.157-203.

ARIKBOĞA, Erbay (2013), “Geçmişten Geleceğe Büyükşehir Belediye Modeli”, Yerel Politikalar Dergisi, S.2(3), ss.48-95.

BULUT, Yakup (1999), "Büyükşehir Yönetimine Kentsel Alt Örgütlenmelerin (STK ve Mahalle) Katılımı: Gaziantep Büyükşehir Belediyesi Örneği", Yayınlanmamış Doktora Tezi, Marmara Üniversitesi Sosyal Bilimler Enstitüsü, İstanbul.

BULUT, Yakup ve KARA, Mehmet (2013), “Köylerin Mahalleye Dönüşmesinin Yansıması Nasıl Olacak? Hatay'da Bir Uygulama”, Kuramdan Uygulamaya Yerel Yönetimler ve Kentsel Politikalar (Ed. Yakup Bulut, Veysel Eren, Sedat Karakaya ve Abdullah Aydın), PEGEM Akademi Yayını, Ankara, ss.267-286.

BULUT, Yakup ve KARAKAYA, Sedat (2016), "Yerel Yöneticilerin Büyükşehir Alglsı", Mustafa Kemal Üniversitesi İIBF Dergisi, S.1(1), ss.1-36.

CANPOLAT, Hasan (2010), "Türkiye'de Son Dönem Yerel Yönetim Reformlarının Yeni Kamu Işsletmeciliği ve Küreselleşme Bă̆lamında Değerlendirilmesi”, Türkiye'de Yerel Yönetimlerin Sorunları ve Geleceği (Ed. Nihat Falay, Ahmet Kesik, Murat Çak ve Mehmet Karataş), Seçkin Yayınları, Ankara, ss.27-61.

ÇELİKYAY, Hicran (2014). "Değişen Kent Yönetimi ve 6360 Sayılı Büyükşehir Yasası”, E-Analiz, SETA Siyaset, Ekonomi ve Toplum Araştırmaları Vakfı Yayını, Ankara. 
DİK, Esra (2014). “6360 Sayılı Kanun Bağlamında Köylerin Mahalleye Çevrilmesi Sorunu”, Mülkiye Dergisi, S.38(1), ss.75-102.

DÖNMEZ, Demet (2018), "Türkiye'de Büyükşehir Yönetimleri Ve Büyükşehirlerin Yeniden Yapılandırlmasina İlişkin Model Arayışları Üzerine Bir İnceleme", Yayınlanmamış Doktora Tezi, Hatay Mustafa Kemal Üniversitesi Sosyal Bilimler Enstitüsü, Hatay.

ELDEM, Hulusi (2016), "Sürdürülebilir Dağlık Alan Yönetimi Çerçevesinde 6360 Sayılı Büyükşehir Belediyelerine İlişkin Kanunun Değerlendirilmesi”, Optimum Ekonomi ve Yönetim Bilimleri Dergisi, S.3(1), ss.83-97.

ERAT, Veysel (2016), "Mahalli İdare Birimi Olarak Köyler ve 6360 Sayılı Yasanın Etkileri”, Bitlis Eren Üniversitesi Akademik İzdüşüm Dergisi, S.1(1), ss.87-98.

GENÇ, Fatma Neval (2014), “6360 Sayılı Kanun ve Aydın'a Etkileri”, Adnan Menderes Üniversitesi Sosyal Bilimler Enstitüsü Dergisi, S.1(Özel Say1), ss.1-29.

HAYIRSEVER TOPÇU, Ferhunde (2015), “6360 Sayll Kanun Çerçevesinde Su Hizmetleri Yönetiminin Değişimi ve Antalya Örneği”, Akdeniz Üniversitesi İïBF Dergisi, S.30, ss.86-121.

KARAARSLAN, Mehmet (2012-2013), "Nasıl Bir Yerel Yönetim? 6360 Sayıl Kanun Üzerine Bir Değerlendirme", Dicle Üniversitesi Hukuk Fakültesi Dergisi, S.17-18(26-27-28-29), ss.123-162.

KARASU, Mithat Arman (2013), “6360 Sayılı Büyükşehir Belediye Kanunu ve Olası Etkileri: Şanlıurfa Örneği”, Gazi Üniversitesi İïBF Dergisi, S.15(1), ss.1-17.

KIZILBOĞA ÖZASLAN, Rüveyda, AKILLI, Hüsniye ve ÖZASLAN, Kamil (2014), "6360 Sayıl Kanun Çerçevesinde Gümüşlük Belde Belediyesi’nin Kapatılmasına İlişkin Yöre Halkının Algısı”, Marmara Üniversitesi İïBF Dergisi, S.36(2), ss.215-235.

ÖNEZ ÇETIN, Zuhal, YILMAZ, Neslihan ve ELDEM, Hulusi (2016), "Büyükşehir Belediyeleri Mali Sisteminin Gelişimi ve 6360 Sayıl Yasanın Gelişime Etkileri: TR32 İlleri Örneği”, Yönetim ve Ekonomi Araştırmaları Dergisi, S.14(4), ss.168-197.

PANK, Çiğdem (2016), “6360 Sayılı Yasa ile Birlikte Bürokraside Meydana Gelen Değişim”, Uluslararası Sosyal Araştırmalar Dergisi, S.9(47), ss.909-916.

SADİOĞLU, Uğur, DEDE, Kadir ve YÜCEYILMAZ, A. Arda (2017), "Yeni Büyükssehir Belediyesi Modelinde Belde Belediyelerin Sonu: Değirmendere Örneği", Hacettepe Üniversitesi İktisadi ve İdari Bilimler Fakültesi Dergisi, S.35(2), ss.95-119.

T. C. CUMHURBAŞKANLIĞI HUKUK VE MEVZUAT GENEL MÜDÜRLÜĞÜ (2019), Mevzuat Bilgi Sistemi (E-Mevzuat), T.C. Cumhurbaşkanlığı, Ankara, www.mevzuat.gov.tr (Erişim Tarihi: 03.03.2019).

YÜKSEL, Cihan (2016), "Yerel Yönetimlerde Kaynak Paylaşım Sistemleri ve 6360 Sayıl Kanun'la Türkiye'deki Değişimler”, Ankara Üniversitesi SBF Dergisi, S.71(3), ss.731-756.

ZENGİN, Ozan (2014), “Büyükşehir Belediye Sisteminin Dönüşümü: Son On Yılın Değerlendirmesi”, Ankara Barosu Dergisi, S.2, ss.91-116.

3030 sayıl1 -MÜLGA- Büyük Şehir Belediyelerinin Yönetimi Hakkında Kanun Hükmünde Kararnamenin Değiştirilerek Kabulü Hakkında Kanun (09.07.1984 tarih ve 18453 sayılı Resmi Gazete).

5216 sayılı Büyükşehir Belediyesi Kanunu (23.07.2004 tarih ve 25531 sayılı Resmi Gazete).

5747 sayılı Büyükşehir Belediyesi Sınırları İçerisinde İlçe Kurulması ve Bazı Kanunlarda Değişiklik Yapılması Hakkında Kanun (22.03.2008 tarih ve 26824 sayılı Resmi Gazete).

6360 sayılı On Dört İlde Büyükşehir Belediyesi ve Yirmi Yedi İlçe Kurulması ile Bazı Kanun ve Kanun Hükmünde Kararnamelerde Değişiklik Yapılmasına Dair Kanun (06.12.2012 tarih ve 28489 sayılı Resmi Gazete). 